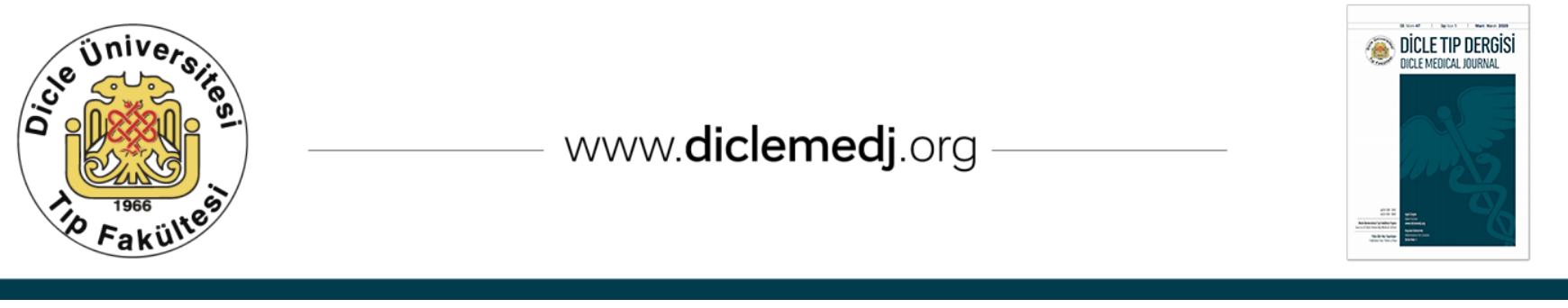

Original Article / Özgün Araştırma

\title{
Analysis of Prognostic Factors Affecting Postoperative Survival in Stage III Gastric Cancer Patients
}

\author{
Yavuz Pirhan1 1 iD \\ 1 Department of General Surgery, Sabuncuoğlu Şerefeddin Research and Training Hospital, Amasya University, Amasya, Turkey
}

Received: 10.10.2019; Revised: 23.12.2019; Accepted: 07.01.2020

\begin{abstract}
Objective: In stage III gastric cancer patients who underwent resection, prognostic factors related to patient, tumor and treatment and their survival effects were investigated.

Method: One-hundred sixty three patients were included in the study and data was obtained retrospectively from hospital records. Investigated parameters; patient-related factors (age,gender,blood group,preoperative hemoglobin,albumin and serum tumor marker (carcinoembryonic antigen(CEA), cancer antigen 19-9(CA 19-9) levels), tumor related factors (tumor localization, tumor size , $\mathrm{T}$ and $\mathrm{N}$ stage, total lymph node count, metastatic/total lymph node ratio, surgical margin of tumor, pathology, differentiation, lymphovascular and perineural invasion status) and treatmentrelated factors (adjuvant treatment, nutritional support, and blood transfusion).

Results: Fifty-one out of the 163 patients were female, and the median age was 60. In univariate analysis, serum Ca19-9 level $(\mathrm{p}=0,03)$, serum CEA level $(\mathrm{p}=0.01)$ and the lymph node ratio $(\mathrm{p}=0.002)$ were found to be an independent factors associated with overall survival whereas only lymph node ratio was an effective parameter in multivariate analysis[ $[\mathrm{p}=$ 0.004 , relative risk $=0.50,95 \%$ confidence interval $(0.32-0.80)]$. When the study was finalized, patients were followed for a median of 16 months, 87 patients (53.4\%) died due to the disease.
\end{abstract}

Conclusion: The metastatic tumor load in the lymph nodes around the stomach was negatively effective on survival. This result demonstrates the importance of lymphatic dissection.

Keywords:Gastric cancer,prognostic factors,survival

DOI: 10.5798/dicletip. 705908

Correspondence / Yazışma Adresi: Yavuz Pirhan, Department of General Surgery, Sabuncuoğlu Şerefeddin Research and Training Hospital, Amasya University, Amasya, Turkeye-mail: ypirhan@gmail.com 


\section{Evre III Gastrik Kanserli Hastalarda Postoperatif Sağkalımı Etkileyen Prognostik Faktörlerin Analizi}

Öz

Amaç: Evre III mide kanserli hastalarda hastaya, tümöre ve tedaviye ilişkin prognostik faktörler ve bunların sağkalıma etkileri araştırıldı.

Yöntemler: Yüz altmış üç hasta çalışmaya dahil edildi ve veriler geriye dönük olarak hastane kayıtlarından elde edildi. İncelenen parametreler; hastaya bağlı faktörler (yaş, cinsiyet, kan grubu, preoperatif hemoglobin, albumin ve serum tümör marker (karsinoembriyonik antijen (CEA), kanser antijeni 19-9 (CA 19-9) seviyeleri), tümör ilişkili faktörler (tümör lokalizasyonu, tümör boyutu) , T ve N evresi, total lenf nodu sayısı, metastatik / total lenf nodu oranı, tümörün cerrahi sınırı, patoloji, farklılaşma, lenfovasküler ve perinöral invazyon durumu) ve tedaviye bağlı faktörler (adjuvan tedavi, beslenme desteği ve kan transfüzyonu).

Bulgular: 163 hastanın 52'si kadın, ortanca yaş 60 idi. Tek değişkenli analizlerde serum Ca 19-9 düzeyi $(p=0,03)$, serum CEA düzeyi $(p=0.01)$ ve lenf nodu oranı $(p=0.002)$ genel sağkalım ile ilișkili bağımsız bir faktör olarak bulunurken, sadece lenf nodu oranı çok değişkenli analizde etkili bir parametre idi [ $(p=0.004$, göreceli risk $=0.50, \% 95$ güven aralı̆̆ (0.32-0.80)]. Çalışma sonlandırıldığında, hastalar ortanca 16 ay boyunca takip edildi, 87 hasta $(\% 53,4)$ hastalık nedeniyle öldü.

Sonuç: Mide etrafındaki lenf nodlarındaki metastatik tümör yükü sağkalım üzerinde olumsuz yönde etkili olmuştur. Bu sonuç lenfatik diseksiyonun önemini göstermektedir.

Anahtar kelimeler: Mide kanseri, mide kanserinde prognoz, prognostik faktörler.

\section{INTRODUCTION}

Gastric cancer remains one of the most common forms of cancer worldwide. Similarly in Turkey, it occupies the third order in women, the second in men, and the third in cancer-related causes of death ${ }^{1,2}$. According to the World Health Organization (WHO), about 1 million new stomach carcinomas are diagnosed per year and $70 \%$ of these new cases are reported from developing countries ${ }^{3}$. The treatment of non-metastatic gastric cancers is curative surgery, yet prognosis is still poor. Today, "curative surgery" is recommended by radical gastrectomy with negative surgical margins, D2 rather than a D1 lymphadenectomy and by gastrectomy with a minimum of 16 regional nodes be assessed pathologically but that removal/evalution of more nodes(30 or more) is desirable ${ }^{4}$.

With the most important prognostic factor in stomach carcinoma patients being the stage of the disease, location, number of lymph node involvement, lymphovascular invasion, perineural invasion, tumor burden, histopathologic type, patient's performance status, and co-morbid diseases are also affecting factors ${ }^{5}$. Although most of the studies consist of all stages of non-metastatic gastric cancer, we studied only stage III of the disease to determine factors affecting survival.

\section{METHODS}

\section{Ethical Consideration}

Ethics committee approval was received from Noninvasive Clinical Research Ethics Committee of University of Amasya(2019-8-42).Informed consent was obtained from the patients. Our work was done in accordance with Helsinki Declaration. Study Group

Information of 275 patients with histologically confirmed adenocarcinoma of the stomach who underwent any type of surgery was obtained retrospectively from hospital records. Patients who were applied paliative surgery, patients with insufficient file information, or no follow-up, and patients who died within the first six months after surgery were not included in the study. Patients were staged according to the National 
Comprehensive Cancer Network (NCCN) 2017 guidelines. Most of the patients were stage III (78\%). Since the factors affecting survival were investigated only 163 patients of stage III were included to the study. Medical records, operation detail, the tumor characteristics, and treatment were noted and survival rates were analyzed. Investigated parameters and classifications, These were; patient-related factors (age, gender, blood group, preoperative hemoglobin, albumin and serum tumor marker (carcinoembryonic antigen (CEA), cancer antigen 19-9 (CA 19-9) levels), tumor related factors (tumor localization, tumor size, $\mathrm{T}$ and $\mathrm{N}$ stage, total lymph node count, metastatic/total lymph node ratio, surgical margin of tumor, surgical margin is negative, pathology, differentiation, lymphovascular, and perineural invasion status) and treatment-related factors (adjuvant treatment, nutritional support and blood transfusion). Patients were grouped according to age as 40 years and younger, between $40-70$ years and over 70 years old, hemoglobin level as $9 \mathrm{~g} / \mathrm{dl}$ and below and 9 and above, and albumin level as 2.5 and less, 2.5-3.5 g/dl, 3.5 and above. The normal limits of serum CEA were $0-10 \mathrm{ng} / \mathrm{ml}$, the normal limits of CA 19-9 were $0-37 \mathrm{U} / \mathrm{ml}$, and the values above these levels were evaluated as high. Tumor size was classified as $5 \mathrm{~cm}$ or less, $5-10 \mathrm{~cm}, 10 \mathrm{~cm}$ or more; the distance of the tumor to surgical margin after resection was classified as $10 \mathrm{~mm}$ and less, 10 $20 \mathrm{~mm}, 20-40 \mathrm{~mm}$, and $40 \mathrm{~mm}$ and over; total lymph node counts were classified as 15 and below, between 15-25 and 25 and above; and the metastatic/total excised lymph node ratio was also classified as 0.25 and below, 0.25-0.50, 0.50-0.75 and 0.75 and above.

\section{Postoperative treatment}

After surgery, only 34 patients were given chemotherapy and 117 patients were given radiotherapy and chemotherapy. Twelve patients did not receive adjuvant treatment. 115 patients received FUFA (5-fluorouracil and leucovorin), 25 patients received FAC (5-fluorouracil, doxorubicin, cisplatin) and 11 patients received TCF (dosetaksel, cisplatin, 5-fluorouracil). Patients receiving chemoradiotherapy received radiation at a dose of 45 Gy for 28 days. Chemotherapy with 5-fluorouracil and calcium folinate was administered for five days at the beginning and at the end of radiotherapy.

\section{Follow-up procedure}

Patients were followed up for every 3 months in the first two years, for six months between 2-5 years, and then yearly. During follow-up, physical examination, complete blood counts, liver function tests, carcinoembryonic antigen and carbohydrate antigen 19.9 were performed. All patients had ultrasonography and/or abdominopelvic tomography and at 6 month intervals and annually thereafter. Gastroscopy was tailored to the individual patient.

\section{Statistical Analysis}

The primary end point of the study was overall survival. Patients were followed up until either to death or to the last date the patient was known to be alive. Descriptive statistics were used to calculate frequencies and percentages for all variables involved. Univariate survival curves for overall survival and death were estimated by using the Kaplan-Meier method; group differences in survival time were tested by the log-rank test. All significant parameters in univariate analyses were entered into a multivariate Cox regression analyses and to calculate risk ratio. $\mathrm{P}$ values of $<0.05$ were considered statistically significant. All analyses were carried out using SPSS software (version 16.0; SPSS Inc, Chicago, IL).

\section{RESULTS}

One hundred sixty three patients were included in this study. Fifty-one of the patients were female, 112 were male and the median age was 60 (border: 1979 years). $41 \%$ out of the 163 patients in stage IIIA, 53 patients in stage IIIB and 69 patients in stage IIIC. The histological subtypes were; adenocarcinoma in 128 patients $(78.5 \%)$ and signet ring carcinoma in 35 patients $(21.5 \%)$. The distribution of cancer's location reported was as follows; cardia in 21 patients $(12.9 \%)$, fundus in 8 patients $(4.9 \%)$, corpus in 58 patients (35.6\%), antrum in 71 patients (43.6\%), and whole stomach (3.1\%). Gastric cancers consist mostly of poorly differentiated (55.2\% patients), well-differentiated cancer was seen quite 
(8\% patients) and the remainder were moderately differentiated.

Patient-related factors affecting survival and outcomes were given Table I.

Table I: Patient-related factors affecting survival and outcomes

\begin{tabular}{|c|c|c|c|c|}
\hline & & No(\%) & $\begin{array}{c}\text { Median survival } \\
\text { time } \\
\text { (min-max } \\
\text { months) }\end{array}$ & $P$ values \\
\hline Age & $\begin{array}{l}\leq 40 \\
40-70 \\
\geq 70\end{array}$ & $\begin{array}{c}11(6.7 \%) \\
131(80.4 \%) \\
21(12.9 \%)\end{array}$ & $\begin{array}{l}19(8-53) \\
16(7-79) \\
14(8-46)\end{array}$ & 0,10 \\
\hline Sex & $\begin{array}{l}\text { Female } \\
\text { Male }\end{array}$ & $\begin{array}{l}51(31.3 \%) \\
112(68.7 \%)\end{array}$ & $\begin{array}{l}15(7-79) \\
16(7-63)\end{array}$ & 0,83 \\
\hline Blood group & $\begin{array}{l}0 \\
\mathrm{~A} \\
\mathrm{~B} \\
\mathrm{AB}\end{array}$ & $\begin{array}{c}54(33.1 \%) \\
78(47.9 \%) \\
27(16.6 \%) \\
4(2.5 \%)\end{array}$ & $\begin{array}{l}16.5(7-63) \\
16(7-79) \\
19(8-62) \\
10.5(8-20)\end{array}$ & 0,25 \\
\hline $\begin{array}{l}\text { Hgb level } \\
\text { before } \\
\text { operation }\end{array}$ & $\begin{array}{l}\leq 9 \mathrm{~g} / \mathrm{dl} \\
>9 \mathrm{~g} / \mathrm{dl}\end{array}$ & $\begin{array}{c}18(11 \%) \\
145(89 \%)\end{array}$ & $\begin{array}{l}14(8-58) \\
16(7-79)\end{array}$ & 0,93 \\
\hline $\begin{array}{l}\text { Alb level } \\
\text { before } \\
\text { operation }\end{array}$ & $\begin{array}{l}\leq 2.5 \mathrm{~g} / \mathrm{dl} \\
2.5-3.5 \\
\mathrm{~g} / \mathrm{dl} \\
\geq 3.5 \mathrm{~g} / \mathrm{dl}\end{array}$ & $\begin{array}{c}15(9.2 \%) \\
95(58.3 \%) \\
53(32)\end{array}$ & $\begin{array}{l}19(8-58) \\
18(7-79) \\
14(7-59)\end{array}$ & 0,14 \\
\hline $\begin{array}{l}\text { Serum Ca19-9 } \\
\text { level }\end{array}$ & $\begin{array}{l}\text { Normal } \\
\text { High } \\
\text { Unknown }\end{array}$ & $\begin{array}{c}102(62.6 \%) \\
31(19 \%) \\
30(18.4 \%)\end{array}$ & $\begin{array}{l}18.5(7-63) \\
14(7-79) \\
12(7-49)\end{array}$ & 0,03 \\
\hline $\begin{array}{l}\text { Serum CEA } \\
\text { level }\end{array}$ & $\begin{array}{l}\text { Normal } \\
\text { High } \\
\text { Unknown }\end{array}$ & $\begin{array}{c}121(74.2 \%) \\
10(6.1 \%) \\
32(19.6 \%)\end{array}$ & $\begin{array}{l}18(7-79) \\
13.5(7-44) \\
12(7-49)\end{array}$ & 0,01 \\
\hline
\end{tabular}

Only serum tumor marker's CEA and CA 19-9 were predictors for survival in univariate analysis. Survival curves were given in Figure 1. and Figure 2.

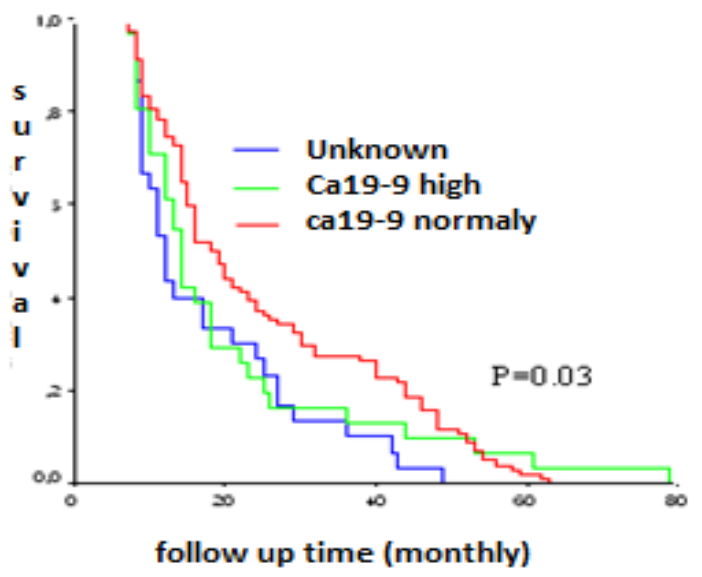

Figure 1: Survival analysis according to ca 19-9 level by Kaplan Meier curve

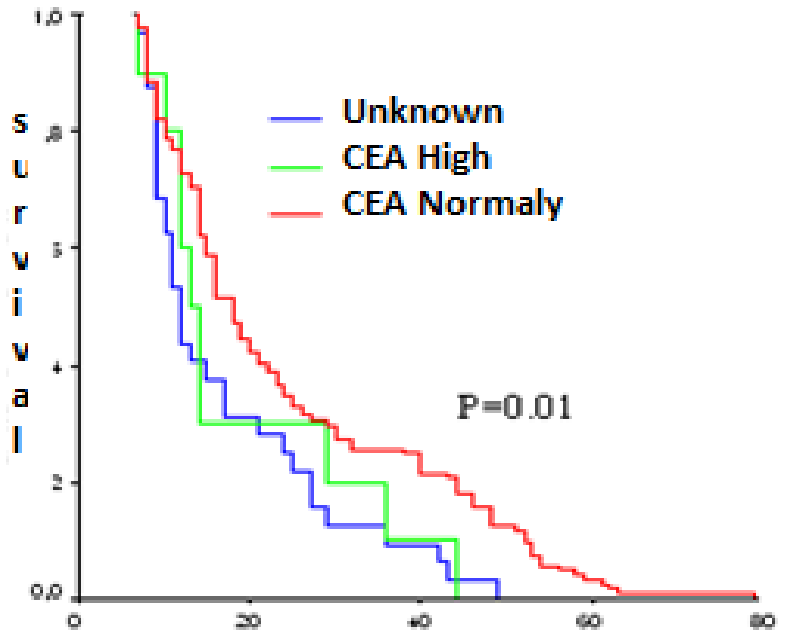

follow up time (monthly)

Figure 2: Survival analysis according to CEA size by Kaplan Meier curve

Tumor-related factors and survival outcomes were shown in Table 2. 
Table II. Tumor-related factors affecting survival and outcomes

\begin{tabular}{|c|c|c|c|c|}
\hline & & No(\%) & $\begin{array}{l}\text { Median survival } \\
\text { time (min-max } \\
\text { months) }\end{array}$ & $P$ values \\
\hline $\begin{array}{l}\text { Tumor } \\
\text { localization }\end{array}$ & $\begin{array}{l}\text { Cardia } \\
\text { Fundus } \\
\text { Corpus } \\
\text { Antrum } \\
\text { All stomach }\end{array}$ & $\begin{array}{c}21(12.9 \%) \\
8(4.9 \%) \\
58(35.6 \%) \\
71(43.6 \%) \\
5(3.1 \%)\end{array}$ & $\begin{array}{l}14(7-53) \\
12(9-51) \\
18(7-61) \\
17(7-79) \\
16(9-54)\end{array}$ & 0,32 \\
\hline Pathology & $\begin{array}{l}\text { Adenocarcinoma } \\
\text { Signet ring cell } \\
\text { carcinoma }\end{array}$ & $\begin{array}{l}128(78.5 \%) \\
35(21.5 \%)\end{array}$ & $\begin{array}{l}16(7-79) \\
15(7-54)\end{array}$ & 0,12 \\
\hline Differentiation & $\begin{array}{l}\text { Well } \\
\text { Moderate } \\
\text { Poor }\end{array}$ & $\begin{array}{c}13(8 \%) \\
60(36.8 \%) \\
90(55.2 \%)\end{array}$ & $\begin{array}{c}13(8-61) \\
18.5(7-62) \\
15(7-79)\end{array}$ & 0,58 \\
\hline T stage & $\begin{array}{l}\mathrm{T} 1 \\
\mathrm{~T} 2 \\
\mathrm{~T} 3 \\
\mathrm{~T} 4 \mathrm{a} \\
\mathrm{T} 4 \mathrm{~b}\end{array}$ & $\begin{array}{c}0 \\
5(3.1 \%) \\
11(6.7 \%) \\
143(87.7 \%) \\
4(2.5 \%)\end{array}$ & $\begin{array}{c}- \\
36(9-48) \\
9(7-59) \\
16(7-79) \\
10(8-23)\end{array}$ & 0,06 \\
\hline N stage & $\begin{array}{l}\mathrm{N} 1 \\
\mathrm{~N} 2 \\
\mathrm{~N} 3 \mathrm{a} \\
\mathrm{N} 3 \mathrm{~b}\end{array}$ & $\begin{array}{l}30(18.4 \%) \\
55(33.7 \%) \\
54(33.1 \%) \\
24(14.7 \%)\end{array}$ & $\begin{array}{l}15(8-61) \\
18(7-54) \\
16(7-79) \\
14(7-62)\end{array}$ & 0,63 \\
\hline $\begin{array}{|lr|}\text { Total } & \text { removed } \\
\text { lymph } & \text { node } \\
\text { count } & \\
\end{array}$ & $\begin{array}{l}\leq 15 \\
15-25 \\
\geq 25\end{array}$ & $\begin{array}{l}50(30.7 \%) \\
58(35.6 \%) \\
55(33.7 \%)\end{array}$ & $\begin{array}{l}14(7-63) \\
16(7-79) \\
22(7-61)\end{array}$ & 0,23 \\
\hline $\begin{array}{l}\text { Metastatic/total } \\
\text { excised lymph } \\
\text { node ratio }\end{array}$ & $\begin{array}{l}\leq 0,25 \\
0,25-0,5 \\
0,5-0,75 \\
\geq 0,75\end{array}$ & $\begin{array}{c}65(39.9 \%) \\
38(23.3 \%) \\
31(19 \%) \\
29(17.8 \%)\end{array}$ & $\begin{array}{c}19(7-61) \\
15.5(7-62) \\
20(8-79) \\
13(7-36)\end{array}$ & 0,002 \\
\hline $\begin{array}{l}\text { Lymphovascular } \\
\text { invasion }\end{array}$ & $\begin{array}{l}\text { Yes } \\
\text { No }\end{array}$ & $\begin{array}{l}107(65.6 \%) \\
56(34.4 \%)\end{array}$ & $\begin{array}{l}16(7-63) \\
16(7-79)\end{array}$ & 0,86 \\
\hline $\begin{array}{l}\text { Perineural } \\
\text { invasion }\end{array}$ & $\begin{array}{l}\text { Yes } \\
\text { No }\end{array}$ & $\begin{array}{l}95(58.3 \%) \\
68(41.7 \%)\end{array}$ & $\begin{array}{c}16(7-62) \\
16,5(7-79)\end{array}$ & 0,30 \\
\hline \begin{tabular}{|l|} 
Surgical margin \\
(millimeters)
\end{tabular} & $\begin{array}{l}\leq 10 \\
10-20 \\
20-40 \\
\geq 40\end{array}$ & $\begin{array}{l}32(19.6 \%) \\
44(27 \%) \\
67(41.1 \%) \\
20(12.3 \%)\end{array}$ & $\begin{array}{c}15.5(8-48) \\
19(7-53) \\
16(7-79) \\
12.5(7-32)\end{array}$ & 0,09 \\
\hline
\end{tabular}

There was no difference in survival between those with a tumor size of $5 \mathrm{~cm}$ or less, those between $5-10 \mathrm{~cm}$ and patients with a height of $10 \mathrm{~cm}$ or more $(\mathrm{p}=0.80$ and $\mathrm{p}=0.47$, respectively). In addition, patients with tumor size of $5-10 \mathrm{~cm}$ and patients with tumor size of $10 \mathrm{~cm}$ and above were similar $(\mathrm{p}=0.42)$. Invasion depth was not an effective parameter for survival $(p=0.06)$. However, the distribution of patients among the groups was not homogeneous. Of the 163 patients in the study, 143 were T4a. In the subgroup analysis, only survival was different between the $\mathrm{T} 4 \mathrm{a}$ patient group and the $\mathrm{T} 4 \mathrm{~b}$ patient group $(\mathrm{p}=$ 0.04). Survival curves were given in Figure 3.

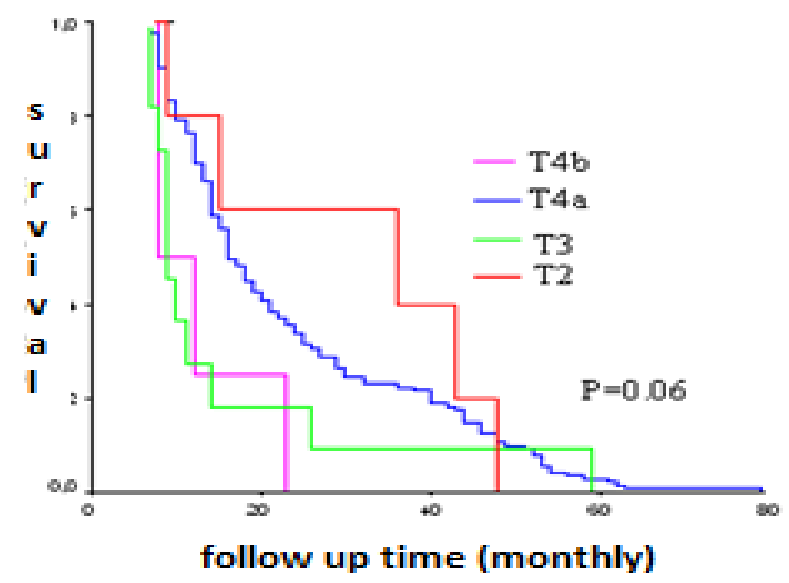

Figure 3: Survival analysis according to invasion depth by Kaplan Meier curve

Among the tumor-related factors, only only the lymph node ratio affected the survival and survival curves were given in Figure 4.

The factors related to the treatment and the survival time were shown in table 3 . 


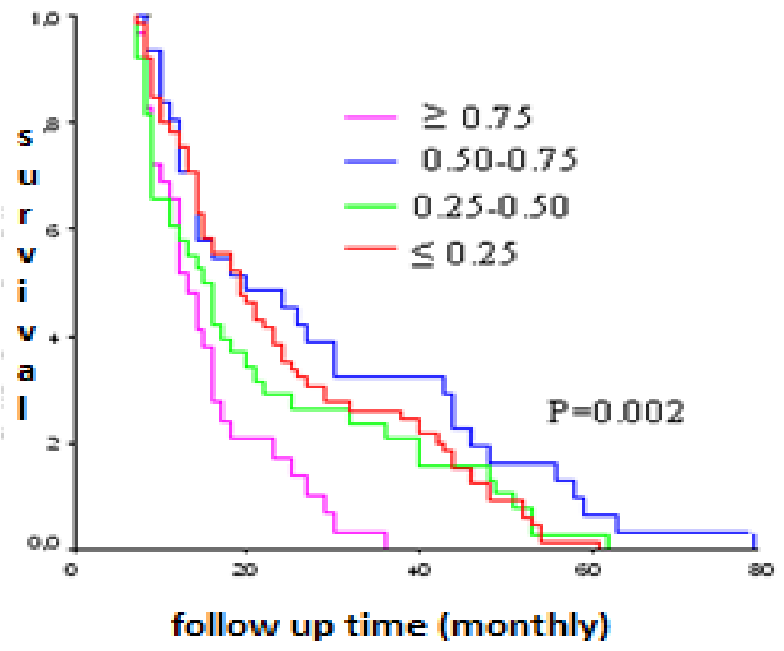

Figure 4: Survival analysis according to lymph node rate by Kaplan Meier curve

Table III: Treatment characteristics and median survival effects

\begin{tabular}{|c|c|c|c|c|}
\hline & & No(\%) & $\begin{array}{c}\text { Median } \\
\text { survival time } \\
\text { (min-max } \\
\text { months) }\end{array}$ & $\mathbf{P}$ \\
\hline $\begin{array}{l}\text { Adjuvant } \\
\text { treatment }\end{array}$ & $\begin{array}{l}\text { CT } \\
\mathrm{CT}+\mathrm{RT} \\
\text { No } \\
\text { treatment }\end{array}$ & $\begin{array}{c}34(20.9 \%) \\
117(71.8 \%) \\
12(7.4 \%)\end{array}$ & $\begin{array}{l}14(8-62) \\
18(7-63) \\
11,5(7-79)\end{array}$ & 0,15 \\
\hline $\begin{array}{l}\text { Blood } \\
\text { transfusion }\end{array}$ & $\begin{array}{l}\text { Yes } \\
\text { No }\end{array}$ & $\begin{array}{l}63(38.7 \%) \\
100(61.3 \%)\end{array}$ & $\begin{array}{l}15(7-62) \\
16(7-79)\end{array}$ & 0,22 \\
\hline $\begin{array}{l}\text { Nutritional } \\
\text { support }\end{array}$ & $\begin{array}{l}\text { Yes } \\
\text { No }\end{array}$ & $\begin{array}{l}115(70.6 \%) \\
48(29.4 \%)\end{array}$ & $\begin{array}{l}16(7-63) \\
16,5(8-79)\end{array}$ & 0,36 \\
\hline
\end{tabular}

CT: ChemotherapyRT: Radiotherapy

The chemotherapy (CT) group lived for 14 months while the chemoradiotherapy (CRT) group lived for 18 months. The overall survival in the CRT group was better but not statistically significant $(p=0.06)$. Survival curves were given in Figure 5.

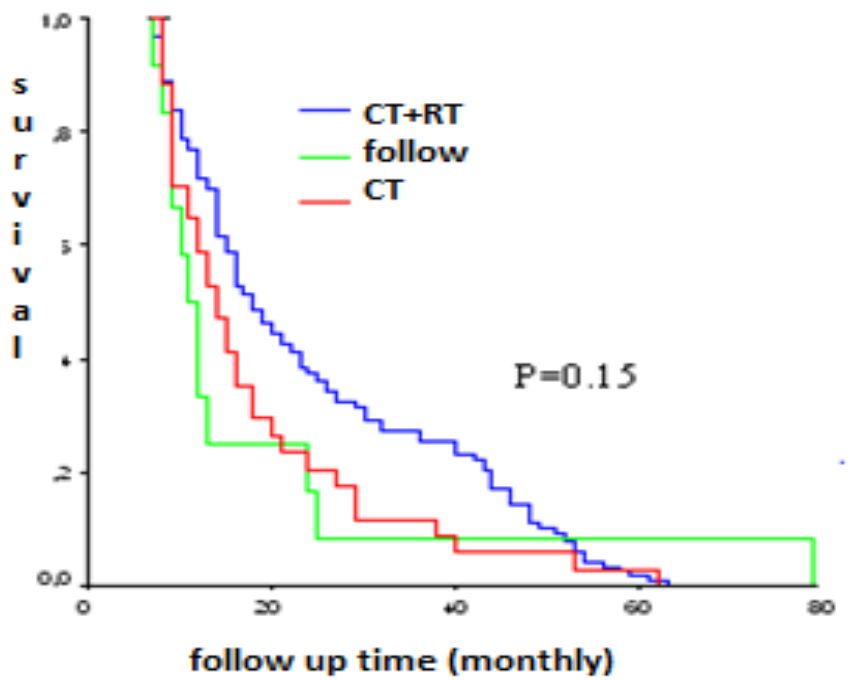

Figure 5: Survival analysis according to adjuvant treatment by

Kaplan Meier curve

In univariate analysis, serum Ca 19-9 level $(\mathrm{p}=0,03)$, serum CEA level $(\mathrm{p}=0.01)$ and the lymph node ratio $(\mathrm{p}=0.002)$ were found to be an independent factors associated with overall survival whereas only lymph node ratio was an effective parameter in multivariate analysis $[(\mathrm{p}$ $=0.004$, relative risk $=0.50,95 \%$ confidence interval $(0.32-0.80)]$. When the study was finalized, patients were followed for a median of 16 months (range: 7-79 months). 87 patients (53.4\%) died due to the disease.

\section{DISCUSSION}

Gastric cancer is still an important cause of cancer-related deaths. In a study consist of 10,092 patients undergoing gastrectomy by Song et al argued that young patients suffer a higher survival rate after surgery compared to elderly patients, and survival becomes worse with increasing age ${ }^{6}$. Sex steroid hormones in gastric carcinoma and their clinicopathological significance is unclear and divergent ${ }^{7}$. Age and sex did not affect survival in our study. 
However, the number of patients over the age of 70 was very low in our series and was limited to only 12 patients. So the effect of survival of old age was not revealed in this study. The incidence of gastric cancer is higher in people with A blood group than in those with 0 blood group $^{8}$. In addition, it is argued that survival is better in patients with A blood group than the ones in 0 blood group. In our study, $70.6 \%$ of gastric cancer patients were in the $\mathrm{A}$ blood group while $33.1 \%$ of the patients were in the 0 blood group. There was no relationship between blood groups and survival.

The stage of the disease, the state of the lymph nodes ( $\mathrm{N}$ stage) and the tumor tissue's invasion grade (T stage) in the stomach wall are the most important factors determining the prognosis 5year overall survival rates were as follows: 5year survival is stage IA (94.7\%), stage IB (89.9\%), stage IIA (80.7\%), stage IIB (72.5\%), stage IIIA (58.4\%), stage IIIB (40.8\%), stage IIIC $(20.2 \%)$, and stage IV $(8.8 \%)^{9}$. For this reason, we studied only stage III diseases. Jun and colleagues argue that tumor size isn't only effect, but tumor invasion depth and metastatic lymph node involvement are the effective factors for survival, as well ${ }^{10}$. Adachi and his colleagues divided the patients into three groups; those with a tumor diameter less than 4 $\mathrm{cm}$, those with a diameter of $4-10 \mathrm{~cm}$ and those with a diameter of $10 \mathrm{~cm}$. They showed that, as the size increased, survival of patients with gastric cancer was adversely affected and this was a prognostic parameter ${ }^{11}$. Saito et al. also found that the appropriate tumor size threshold to affect survival was $8 \mathrm{~cm}$ and that tumor size was an independent factor that would affect survival ${ }^{12}$. In our study we did not detect any effect of tumor size on survival. There are a large number of researchers who argue that the depth of tumor invasion affects survival ${ }^{13}$. However, there are also some who argue that the depth of tumor invasion and stage does not affect the prognosis ${ }^{14}$. The depth of tumor invasion was not found as an effective parameter for survival in our study. However, the distribution of patients among the groups was not homogeneous. In the sub-group analysis, only survival was different between the $\mathrm{T} 4 \mathrm{a}$ patient group and the $\mathrm{T} 4 \mathrm{~b}$ patient group. Survival is increasing in direct proportion to the number of lymph nodes removed. To mention a good lymph node dissection, over ${ }^{15}$ lymph nodes should be dissected in the D2 dissection ${ }^{15}$. In our series, the median number was ${ }^{20}$. Patients were found to be more alive when the number of removed lymph nodes was increased, but this effect was not statistically significant. Lymph node metastasis is the another important prognostic factor in gastric cancer ${ }^{16}$. As the number of metastatic lymph nodes increases, survival decreases, which is the increase of the disease stage. In studies conducted by Oh Cheong et al. with 3979 patients, and Roberto Persiani et al. with 219 patients, survival decreased as the number of metastatic lymph nodes increased ${ }^{17}$. In our series, the survival differences was not seen, it may be all the patients in the same stage. Like our study, Chen et al have found that metastatic lymph node ratio was also important prognostic and predictive value in stage III gastric cancer ${ }^{18}$. The effect of lymphovascular invasion and perineural invasion on survival is controversial. Ersan $\mathrm{Y}$ et al. have argued that lymphovascular invasion and perineural invasion are not the sole cause but are more significant with factors such as tumor size, surgical margin, lymph node ratio, etc. ${ }^{19}$, while Bilici et al.'s research with 238 patients have shown that the presence of perineural invasion in the disease series is a prognostic factor ${ }^{20}$. In our study, lymphovascular invasion and perineural invasion did not affect survival. Whether prognostic significance of proximal surgical margin especially advanced carcinoma is not clear. Ohe et al. study results considered that a sufficient resection margin is not the absolute factor associated with the rate of 
survival and recurrence ${ }^{21}$. In this study, the surgical margin had no effect on survival.

While surgical treatment is the strongest predictor of long-term survival, poor results with surgery alone, especially in patients with stage III disease. In nowadays, adjuvant and neoadjuvant approaches using chemotherapy, radiation therapy, or a combination of the two are recommended ${ }^{22,23}$. However, perioperative chemotherapy versus postoperative chemoradiotherapy in patients with resectable gastric is controversial ${ }^{24,25}$. In our study, chemoradiotherapy receiving patients had a better life expectancy than patients receiving only chemotherapy but this difference was not significant.

In a conclusion, the metastatic tumor load in the lymph nodes around the stomach was negatively affect on survival.Manuscript wasn't presented as part at a meeting, the organization, place, and exact date on

Author meet the ICMJE authorship criteria

My work was done in accordance with helsinki declationa. Patients included in the study were informed about the patient before and after the study.

Financial support: No financial support was received from any institution or organization when the study was conducted.

There is no conflict of interest.

Acknowledgements: I thanks Mr. Ali Duran for excellent language assistance.

Patient Recognition: Informed consent was obtained from the patients

Ethics Committee Approval: Ethics committee approval was received from Non-invasive Clinical Research Ethics Committee of University of Amasya (2019-8-42).

Interest was declared by the authors

\section{REFERENCES}

1. Karimi $\mathrm{P}$, Islami $\mathrm{F}$, Anandasabapathy $\mathrm{S}$, Freedman Nd, Kamangar F. Gastric Cancer: Descriptive Epidemiology, Risk Factors, Screening, And Prevention. Cancer Epidemiol Biomarkers Prev. 2014; 23: 700-13.

2. World Health Organization. International Agency For Research On Cancer. Globocan Turkey. 2012.

3. World Health Organization. Cancer. Accessed 11 Aug 2013. Available From: Url: Http://Www.Who.Int/Mediacentre/Factsheets /Fs297/En/

4. Ajani Ja, In H, Sano T, et al. Stomach. In: AJCC Cancer Staging Manual, 8th, Amin Mb. (Ed), AJCC, Chicago. 2017; pp. 203.

5. Amini N, Spolverato G, Kim Y, et al.Clinicopathological Features And Prognosis Of Gastric Cardia Adenocarcinoma: A MultiInstitutional U.S. Study. J Surg Oncol.2015; 111: 285-92.

6. Song $\mathrm{P}, \mathrm{Wu} \mathrm{L}$, Jiang $\mathrm{B}$, et al. Age-Specific Effects On The Prognosis After Surgery For Gastric Cancer: A Seer Population-Based Analysis. Oncotarget. 2016; 7: 48614-24.

7. Wesołowska M, Pawlik P, Jagodziński Pp. The Clinicopathologic Significance Of Estrogen Receptors In Human Gastric Carcinoma. Biomed Pharmacother.2016; 83: 314-22.

8. Etemadi A, Kamangar $F$, Islami $F$, et al. Mortality And Cancer In Relation To Abo Blood Group Phenotypes In The Golestan Cohort Study. BMC Med. 2015; 13: 8.

9. Kim Sg, Seo Hs, Lee Hh, Song Ky, Park Ch. Comparison of The Differences In Survival Rates Between The 7th And 8th Editions Of The AJCC TNM Staging System For Gastric Adenocarcinoma: A single-institution study of 5,507 patients in Korea. J Gastric Cancer. 2017; 17: 212-9. 
10. Jun Kh, Jung H, Baek Jm, Chin Hm, Park Wb. Does Tumor Size Have An Impact On Gastric Cancer? A Single Institute Experience. Langenbecks Arch Surg. 2009; 394: 631-5.

11. Adachi Y, Oshiro T, Mori M, et al. Tumor Size As A Simple Prognostic Indicator For Gastric Carcinoma. Ann Surg Oncol. 1997; 4: 137-40.

12. Saito H, Osaki T, Murakami D, et al. Macroscopic Tumor Size As A Simple Prognostic Indicator In Patients With Gastric Cancer. Am J Surg. 2006; 192: 296-300.

13. Zhou Y, Cui Jg, Huang F, et al. Prognostic Factors For Survival In Node-Negative Gastric Cancer Patients Who Underwent Curative Resection.Scand J Surg. 2017;106: 235-40.

14. Wang Z, Zhang X, Hu J, Zeng W, Zhou Z. Clinicopathological Features And Outcomes In Patients Undergoing Radical Resection For Early Gastric Cancer With Signet Ring Cell Histology. J Visc Surg. 2015; 152:357-61.

15. Ji $\mathrm{X}, \mathrm{Bu} \mathrm{Zd}, \mathrm{Li} \mathrm{Zy}$, et al. Prognostic Significance Of The Total Number Of Harvested Lymph Nodes For Lymph Node-Negative Gastric Cancer Patients. BMC Cancer. 2017; 17: 558.

16. Espín F, Bianchi A, Llorca S, et al. Metastatic Lymph Node Ratio Versus Number of Metastatic Lymph Nodes As A Prognostic Factor In Gastric Cancer. Eur J Surg Oncol. 2012; 38: 497-502.

17. Cheong O, Kim Bs, Yook Jh, et al. Modified radical lymphadenectomy without splenectomy in patients with proximal gastric cancer: Comparison with standard D2 lymphadenectomy for distal gastric cancer. Journal of Surgical Oncol. 2008; 98: 500-4.

18. Chen Y, Li C, Du Y, et al. Prognostic And Predictive Value of Metastatic Lymph Node Ratio In Stage Iii Gastric Cancer After D2 Nodal Dissection. Oncotarget.2017; 8: 70841-6.
19. Ersan Y, Ertürk S, Çiçek Y, et al. Early And Late Results Of Curative Resection In Cases Of Gastric Carcinoma. Cerrahpaşa J Med 2003; 34: 178-84.

20. Bilici A, Seker M, Ustaalioglu Bb, et al. Prognostic Significance Of Perineural Invasion In Patients With Gastric Cancer Who Underwent Curative Resection. Ann Surg Oncol. 2010; 17: 2037-44.

21. Ohe H, Lee Wy, Hong Sw, Chang Yg, Lee B. Prognostic Value of The Distance Of Proximal Resection Margin In Patients Who Have Undergone Curative Gastric Cancer Surgery. World J Surg Oncol. 2014; 12: 296.

22. Smalley Sr, Benedetti Jk, Haller Dg, et al. Updated Analysis Of Swog-Directed Intergroup Study 0116: A Phase III trial of adjuvant radiochemotherapy versus observation after curative gastric cancer resection. J Clin Oncol. 30: 2327; 2012

23. Ronellenfitsch U, Schwarzbach M, Hofheinz $\mathrm{R}$, et al. Adenocarcinoma meta-analysis group. Perioperative chemo(radio)therapy versus primary surgery for resectable adenocarcinoma of the stomach, gastroesophageal junction, and lower esophagus. Cochrane Database Syst Rev. 2013; Cd008107.

24. Lee J, Lim Do H, Kim S, et al. Phase III trial comparing capecitabine plus cisplatin versus capecitabine plus cisplatin with concurrent capecitabine radiotherapy in completely resected gastric cancer with D2 lymph node dissection: The Artist Trial. J Clin Oncol.2012; 30: 268-73.

25. Kim Th, Park Sr, Ryu Kw, et al. Phase III trial of postoperative chemotherapy alone versus chemoradiation therapy in Stage III-IV gastric cancer treated with R0 gastrectomy and D2 lymph node dissection. Int J Radiat Oncol Biol Phys2012; 84: E585-92. 